\title{
Reasons for Living of Elderly in Old Age Homes: \\ An Exploratory Study
}

\author{
Shamsi Akbar*, S.C.Tiwari**, Rakesh Kumar Tripathi***, Ambrish Kumar****, \\ Nisha Mani Pandey*****
}

\section{ABSTRACT:}

Background: Now-a-days, almost all the old age homes (OAHs) in India are fully occupied with residents. Why Indian elderly have to reside in old age homes? It was explored during the Ph.D. study titled 'A Study of Psychiatric Morbidity, Quality of Life and Expectations of Inmates of Old Age Homes in Northern India'. The object of this study was to explore the factors compelling elderly to reside in old age homes.

Methods: This study was carried out on 174 elderly residing in 14 different OAHs of Uttar Pradesh, India. Factors responsible for their settlement in OAHs were explored using interview method.

Results: Misbehaviour of son and daughters-in-law (29.8\%) was found to be most common reasons for residing in old age home.

Conclusions: Many elderly in India are opting OAHs as their place of stay in their later life. Foreseeing the future the government and voluntary agencies in India must make arrangements for institutional support and care for the elderly.

Keywords: Old age home, elderly, compelling factors, exploratory study.

\section{INTRODUCTION}

Population ageing is one of the most discussed global phenomena in the present century. Countries with a large population like India have a large number of people now aged 60 years or more. The population over the age of 60 years has tripled in last 50 years in India and will relentlessly increase in the near future.

*Research Scholar, Corresponding author, King George's Medical University, UP, Lucknow, India

**Professor \& Head, King George's Medical University, UP, Lucknow, India

***Assistant Professor, King George's Medical University, UP, Lucknow, India

****Social Worker, King George's Medical University, UP, Lucknow, India

*****Senior Research Officer, King George’s Medical University, UP, Lucknow, India

(C) 2014 S Akbar, S Tiwari, R Tripathi, A Kumar, N Pandev; licensee IJIP. This is an Open Access Research distributed under the terms of the Creative Commons Attribution License (http://creativecommons.org/licenses/by/2.0), which permits unrestricted use, distribution, and reproduction in any Medium, provided the original work is properly cited. 
According to census 2001, older people were $7.7 \%$ of the total population, which increased to $8.14 \%$ in census 2011. The projections for population over 60 years in next four censuses are: 133.32 million (2021), 178.59 (2031), 236.01 million (2041) and 300.96 million (2051). The increases in the elderly population are the result of changing fertility and mortality regimes over the last 40-50 years (Ministry of Health and Family Welfare, 2011) \& (Central Statistics Office, New Delhi, 2011). With the rapidly increasing number of aged, the care of elderly has emerged

as an important issue in India. Providing care for the aged has never been a problem in India where a value based joint family system was dominant. This family structure has been the socioeconomic backbone of the average Indian (Shah, 1998). During ill health or emergency or any critical position, family members were taking the responsibilities and sharing the burden to help each other. The families also were sharing the responsibility to look after their elderly by giving them all kind of support including emotional, psychological, behavioural or economic. They were getting full respect and value. Their advices were also being received by younger generation and were revered and honoured. They were living in the family till the end of their life. With the increasing influence of modernization and new life styles resulting in transitional changes in value system in recent times, the 'joint family' is breaking down into several scattered nuclear families (Shah, 1998). Change in family structure and contemporary changes in the psycho-social matrix and values often compel the elderly to live alone or to shift from their own homes to some institutions or old age homes (Dotty, 1992, Hegde et al, 2012, Kumar et al, 2012, Devi et al, 2013, Mishra, 2008 \& Mudey et al, 2011). OAHs are coming in existence as a newer occupancy for elderly and becoming the need of present Indian society. The recent data shows that there are more than 1,000 old age homes in India and most of them are located in the south India. There are of two types of old age homes: free and paid. The "free" type care homes are for the destitute old people who have no family to care and support for them. In such OAHs shelter, food, clothing and medical care etc. are being provided free of cost. In the paid type, all types of services are available for a price.

However, hardly studies explored the factors responsible to compel elderly to reside in OAHs. Therefore, an attempt was made to explore factors responsible to force elderly to reside in OAHs leaving their own homes.

\section{METHOD:}

Study Location: Old age homes of district Bareilly, Lucknow and Varanasi.

Study Design: Cross-sectional exploratory study.

Sample size: A total of 174 elderly residing in OAHs were included in the study.

Inclusion criteria: (a) elderly aged 60 years and above residing in old age homes and able to communicate. (b) Staying in old age homes since six months or more. (c) Able to understand, comprehend and reply to questions and (d) given written informed consent.

Exclusion criteria: (a) Non-cooperative due to any reason (b) any physical problems interfering with interview (e.g. problem in Speech, Hearing, and Vision). 
Assessment Tool: Semi-structured proforma to gather socio-demographic details and an open ended question to solicit the factor responsible for their stay in OAHs.

Procedure: This study is a part of the Ph.D. study titled "a study of psychiatric morbidity, quality of life and expectations of inmates of Old Age Homes in Northern India". The study is being carried out in the Department of Geriatric Mental Health, King George's Medical University, Lucknow. Initially, a total of 21 old age homes from Bareilly (3), Lucknow (5), and Varanasi (13) districts were identified by Help Age India Old Age Homes Directory 2009 and local resources. Out of the 21 old age homes, 5 were non-existent in Varanasi. The researcher has approached the concerning authorities of these 16 identified old age homes and briefed about the purpose of the study but 2 of them have refused to give consent for the study. The reasons for non-cooperation were (i) the study will take time and (ii) the study will involve an extra manpower from the old age home. So, a total of 14 old age homes were selected. A total of 258 elderly residents from these old age homes were screened for the study. Eighty four of them were excluded as per inclusion/exclusion criteria and 174 subjects were screened as the study sample. After initial rapport building and seeking written informed consent, the socio-demographic details were obtained on a semi-structured proforma. To explore the reasons/factors compelled them to shift from their own homes to the OAHs an interview was done. Data was analyzed using percentage statistics.

\section{RESULTS:}

A total of 174 older adults participated in the study. Table 1 provides their socio-demographic details.

Table-1: Socio-demographic profile of OAH residents

\begin{tabular}{|c|c|c|c|c|}
\hline \multirow{2}{*}{\multicolumn{2}{|c|}{ Socio-demographic details }} & \multicolumn{2}{|l|}{ Gender } & \multirow{3}{*}{$\begin{array}{l}\begin{array}{l}\text { Total } \\
(\mathrm{N}=174)\end{array} \\
73(41.9 \%)\end{array}$} \\
\hline & & \multirow{2}{*}{$\begin{array}{l}\text { Male } \\
\mathbf{2 5 . 3 \%}) \\
14(19.2 \%)\end{array}$} & \multirow{2}{*}{$\begin{array}{l}\begin{array}{l}\text { Female } \\
(\mathbf{N}=\mathbf{1 3 0 , 7 4 . 7 \%})\end{array} \\
59(80.8 \%)\end{array}$} & \\
\hline \multirow{3}{*}{$\begin{array}{l}\text { Age } \\
\text { (Mean: } \\
72.8 \text { yrs) }\end{array}$} & $60-69$ & & & \\
\hline & $70-79$ & $11(19.6 \%)$ & $45(80.4 \%)$ & $56(32.2 \%)$ \\
\hline & 80 year $\&$ above & $19(42.2 \%)$ & $26(57.8 \%)$ & $45(25.9 \%)$ \\
\hline \multirow{4}{*}{$\begin{array}{l}\text { Education } \\
\text { (Mean: } 6.6 \\
\text { yrs) }\end{array}$} & Illiterate & $05(7.9 \%)$ & $58(82.1 \%)$ & $63(36.2 \%)$ \\
\hline & Up to $8^{\text {th }}$ & $09(20.9 \%)$ & $34(79.1 \%)$ & $43(24.7 \%)$ \\
\hline & Up to $12^{\text {th }}$ & $08(25.8 \%)$ & $23(74.2 \%)$ & $31(17.8 \%)$ \\
\hline & Graduate and above & $22(59.4 \%)$ & $15(40.6 \%)$ & $37(21.3 \%)$ \\
\hline Marital & Married & $14(8.0 \%)$ & $22(12.6 \%)$ & $36(20 \%)$ \\
\hline
\end{tabular}


Reasons for Living of Elderly to In Old Age Homes: An Exploratory Study

\begin{tabular}{|c|c|c|c|c|}
\hline \multirow[t]{5}{*}{ Status } & Alone & & & \\
\hline & $\begin{array}{l}\text { Married } \\
\text { together }\end{array}$ & $08(4.5 \%)$ & $08(4.5 \%)$ & $16(9.1 \%)$ \\
\hline & Never married & $05(33.3 \%)$ & $10(66.7 \%)$ & $15(8.6 \%)$ \\
\hline & Widow/widower & $15(15 \%)$ & $85(85 \%)$ & $100(57.5 \%)$ \\
\hline & Divorced & $02(28.6 \%)$ & $05(71.4 \%)$ & $07(4.0 \%)$ \\
\hline \multirow[t]{3}{*}{ Occupation } & $\begin{array}{l}\text { Household work ( } \\
\text { no productive work } \\
\text { for male) }\end{array}$ & $10(8.1 \%)$ & $113(91.9 \%)$ & $123(70.7 \%)$ \\
\hline & Pensioner & $2564.1 \%)$ & $14(35.9 \%)$ & $39(22.4 \%)$ \\
\hline & Business /others & $09(75 \%)$ & $03(25 \%)$ & $12(6.9 \%)$ \\
\hline
\end{tabular}

Socio-demographic indicators included Age, Gender, Educational level, and Occupational and marital status. Mean Age of the sample was $72.8 \mathrm{yrs}$ while mean of the education was $6.6 \mathrm{yrs}$. Socio-demography details showed that most of the OAHs residents were females (74.7\%), aged between $60-69$ years $(41.9 \%)$, either illiterate or educated only up to $8^{\text {th }}(60.9 \%)$, widow/widower (57.5\%) and were involved in household work (70.7\%).

Table-2- Factors compelling elderly to reside in old age homes

\begin{tabular}{|c|c|c|}
\hline S.No & Factors & No $(\%)$ \\
\hline 1 & Misbehaviour of son and daughters-in-law & $52 \quad(\mathbf{2 9 . 8 \%})$ \\
\hline 2 & Poverty/ no financial support & $51 \quad(\mathbf{2 9 . 3 \%})$ \\
\hline 3 & To serve the almighty God & $16 \quad(9.1 \%)$ \\
\hline 4 & Loneliness & $14 \quad(8.0 \%)$ \\
\hline 5 & Adjustment problem & $10 \quad(5.7 \%)$ \\
\hline 6 & Nuclear family system & $09 \quad(5.1 \%)$ \\
\hline 7 & Having no son & $09 \quad(5.1 \%)$ \\
\hline 8 & Settlement of children at abroad & $04 \quad(2.2 \%)$ \\
\hline 9 & Children do not want to keep due to psychiatric and/or physical illness & $04 \quad(2.2 \%)$ \\
\hline 10 & Life threats from children & $(1.7 \%)$ \\
\hline 11 & To live independently/ unable to tolerate interference of family members & $02 \quad(1.1 \%)$ \\
\hline
\end{tabular}


The factors compelled the OAHs residents for residing in old age homes are provided in table-2. The most common reasons were misbehaviour of children $(29.8 \%)$ and poverty/no financial support (29.3\%). Other factors were to serve the almighty GOD (9.1\%), loneliness (8.0\%), adjustment problem (5.7\%), nuclear family system $(5.1 \%)$, having no son $(5.1 \%)$, children settled in abroad $(2.2 \%)$, children do not want to keep the elderly due to their physical \& psychiatric illness $(2.2 \%)$, life threats from children $(1.7 \%)$ and better facility in old age home (1.1\%).

\section{DISCUSSION:}

Majority of the old age home residents were aged between 60-69 years which is similar to the study done by Hegde et al, (2012). Majority of the elderly were females, either illiterate or educated up to $8^{\text {th }}$ and widow/widower, similar findings were obtained by a previous study (Tiwari et al, 2012). Most of the female inmates of OAHs said that they were house wives and spent their whole time in doing house hold works and were having no financial gains for their livelihood which forced them to depend on their family. This was the major factor which compelled them to opt OAHs for rest of their life.

A number of studies have discussed various reasons for the elderly to be in old age home. Lack of care in the family, insufficient housing, economic hardship and break-up of joint family are cited as reasons by studies carried out by Bansod et al, (2006), Bharati, (2009) and Mishra et al, (2008). Present study reports "misbehaviour of children" (29.8\%) as most common factor for residing in old age home, is supported by the study done by Lalan, (2014) and Gupta et al, (2014). In this study, the OAHs residents, who reported "poverty" as the reason, was mainly belonging to labor class. In their old age, neither they had money nor were they able to earn money due to their weakness and inability to work. Their children were also doing the same job and they were not in condition to support their parents. That's why they had to come to the old age home for living. "Poverty" $(29.3 \%)$ as the reason for living in old age homes is also supported by many of the studies carried out by Lalan, (2014), Gupta et al, (2014), Siddhu et al, (2010) and Gurushekhran, (2008). "Having no sons" was also found to be a factor, mentioned by residents for coming to OAHs; these inmates informed that they were having daughters to look after. They further explained that they did not want to live with their married daughters as it is believed that a parent who lives with married daughter will not get relief (Moksha) after death. Therefore, they have opted OAHs as their residence. Similar findings were obtained by Siddhu, (2010) and Lalan, (2014). "To serve the almighty GOD", cited as one of the reasons specifically by the residents of OAHs in Varanasi, which is believed as religious capital among the Hindus. The Hindu devotee come here for prayer and spiritual pursuits in last phase of life and wish to die at this place because it is believed as "door to heaven". This finding is supported by Panigrahi et al, (2012) and Gupta et al, (2014). Elderly residents mentioning "loneliness" as the reason, is supported by the study by Dubey et al, (2011) and Gupta et al, (2014). "Adjustment problem" is supported by the study done by Siddhu, (2010). "Settlement of children at abroad" is again supported by the study by Gupta et al, (2014). Nuclear Family System has also been expressed as one of the reasons for shifting to old age homes. The tradition of joint family in the 
culture of Indian society is disappearing slowly, which was based on the love, affection and tradition. It has also transformed the life of family. People have started believing in "Nuclear family" rather than combined or joint. It has made people to live with his own family which including husband, wife and their children. This culture has also affected the emotion of each individual person. In today's time parents afraid from their children, that's why they have started refusing to live with them (children). Due to this reason they have started moving in the old age home (Lalan, 2014). The resident, who belonged to the well to do section of the society, stated that they came to the old age home to lead an independent and peaceful life without any interference. This finding is supported by Panigrahi et al, (2012).

\section{CONCLUSION:}

Misbehaviour of children, financial crisis often lead to feeling of ignorance and lack of emotional support in elderly which often compel them to opt other places for living a problem free life. And, in present scenario along with other reasons OAHS are being considered as a better alternative to reside. There is a need to generate emotional support facilities in these homes and the government and voluntary agencies in India must make arrangements for institutional support and care for the elderly.

Conflict of interest declaration: The authors declare that they have no conflict of interest.

Description of authors' roles: SA: Ph.D. student, collected, analysed, interpreted the data and drafted the manuscript. SCT: Ph.D. guide, conceptualised and designed the study, gave comments on the drafts of the manuscript. RKT: Ph.D. co-guide, conceptualised and designed the study, gave comments on the drafts of manuscript. AK: searched the related literature, analysed and interpreted the data and edited the manuscript. NMP: Ph.D. co-guide, conceptualised and designed the study, gave comments on the drafts of manuscript. All authors approved the final manuscript.

\section{ACKNOWLEDGEMENTS:}

The authors are thankful to the administrative personnel of the OAHs for their cooperation in the study. Authors also greatly appreciate the OAHs residents for participating in the study.

\section{REFERENCE:}

1. Bansod, D., Paswan, B. (2006). From Home to Old Age Home: A Situational Appraisal of Elderly in Old Age Home in Maharashtra. Help Age India Research and Development Journal; 12 (3): 14-23.

2. Bharati, K. (2009). Old Age Homes: New Face of Old Age Care in India. Help Age India Research and Development Journal; 15 (2): 13-18

3. Central Statistics Office, Ministry of Statistics and Programme Implementation, Government of India, New Delhi, (2011). Situation Analysis of the Elderly in India. 
4. Director General of Health Services, Ministry of health \& family welfare, Government of India, New Delhi. (2011). National Program for Health Care of the Elderly.

5. Dotty, P.J. (1992). The oldest old and the use of institutional long term care from an international perspective. In The oldest old (eds. R. Suzman, DP Willis, KG Manton). New York: Oxford University Press; 250-259.

6. Dubey, A., Bhasin, S., Gupta, N. \& Sharma, N. (2011). A study of elderly living in old age home and within family set-up in Jammu, Studies on Home Community Science; 5(2): 93-98

7. Gupta, A., Mohan, U., Tiwari, S.C., Singh, S.K., \& Singh, V.K. (2014). Quality of life of elderly people and assessment of facilities available in old age homes of lucknow, India. National Journal of Community Medicine; 5(1): 21-24.

8. Hegde V.N, Kosgi S., Rao S., Pai. N \& Mudgal S.M. (2012). A Study of Psychiatric and Physical Morbidity among Residents of Old Age Home. International Journal of Health Sciences \& Research; 2(1): 57-74.

9. Kumar,P., Das A., Rautela U. (2012) Mental and Physical Morbidity in Old Age Homes of Lucknow, India. Delhi Psychiatry Journal; 15(1): 111-117.

10. Lalan, Y. (2014). A Sociological Study of Old Persons Residing in an Old age Home Delhi, India. International Research Journal of Social Sciences; 3(4): 21-23,

11. McConnel, C.E. (1984). A note on the life time risk of nursing home residency. Gerontology; 24(2): 193-198.

12. Mishra,Jayanta, A. (2008). A Study of the Family Linkage of the Old Age Home Residents in Orissa. Indian Journal of Gerontology; 22 (2): 196-212.

13. Mudey, A., Ambekar S., Goyal, R.C., Agarekar, S.,Wagh, V.V. (2011). Assessment of Quality of Life among Rural and Urban Elderly Population of Wardha District, Maharashtra, India. Ethno Med; 5(2): 89-93.

14. Murtaaugh C.M., Kemper, P., \& Spillman, B.C., (1990). Risk Factors of Nursing Home Use in Later Life. Med Care; 28(10): 952-962.

15. Panigrahi, A.K., Syamala, T. S. (2012). Living Arrangement Preferences and Health of the Institutionalised Elderly in Odisha. ISEC Working Paper Series; 291.

16. S, Gunasekaran., S,Muthukrishnaveni. (2008). Living Condition and Health Status of Elderly in Old Age Homes. Helpage india Research \& Development Journal; 14 (3): 818.

17. Shah, A.M. (1998). The Family in India: Critical Essays. Orient Longman Limited.

18. Sidhu, G.V. (2010). Helpage India Research \& Development Journal; 16(2): 24-31.

19. Tiwari, S.C., Pandey, N. M., Singh. I., (2012). Mental health problems among inhabitants of old age homes: A preliminary study. Indian Journal of Psychiatry; 54(3): 6-10. 